\title{
The Mediating Effect of HRM Outcomes (employee retention) on the Relationship between HRM Practices and Organizational Performance
}

\author{
Fathi Mohamed Abduljlil ALDamoe \\ College of Business, Universiti Utara Malaysia, Malaysia \\ Tel: +60175443825, E-mail: ft7712@yahoo.com \\ Dr. Mohamd Yazam \\ College of Business, Universiti Utara Malaysia, Malaysia \\ Dr. Kamal Bin Ahmid \\ College of Business, Universiti Utara Malaysia, Malaysia
}

Accepted: December 2, 2011 Published: January 9, 2012

doi:10.5296/ijhrs.v2i1.1252 URL: http://dx.doi.org/10.5296/ijhrs.v2i1.1252

\begin{abstract}
The matter of human resources activities have been commonly used to observe organizational performance. One of the distinctive features of HRM is that better performance is achieved through the people in the organization. In recent years significant remarks have been recorded in identifying the Human Resources Management (HRM) - performance relationship. The relationship between HRM practices and organizational performance has been well documented by the previous studies. However, authors have called for the interrogation of the mediating role of HRM Outcomes such as employee retention in the relationship between HRM practices and organizational performance. Thus, the major objective of this study is to investigate the mediating effect of HRM Outcomes (employee retention) on the relationship between HRM practices and organizational performance. Based on the evidence derived from the literature, the paper concludes that employee retention is likely to mediate in the relationship between HRM practices and organizational performance.
\end{abstract}

Keywords: Human Resources Management, Employee Retention, Human Resources Management Practices, Organizational Performance 


\section{Introduction}

Generally, organizations come in all shapes and sizes and more often exhibit differences than similarities. However, one common factor among these organizations is their "achieved success" which dependent on the skill, knowledge and experience of the employees in the organization (Development and Learning organizations, 2011). This is more reason the matter of human resources activities have been commonly used to observe organizational performance. This further demonstrates the distinctive feature of HRM in achieving better performance through the people in the organization (Guest, 1997). In the recent years, significant remarks have been made in identifying the Human Resources Management (HRM) - performance relationship. However, few studies have documented the special relationship between human resources practices and firm or organizational performance in different contexts.

Abundant studies exist that documented the significant relationship between HRM practices and organizational performance. For instance, Katou (2008) noted that HRM practices have a direct influence or effect on subordinate attributes such as human skills, attitudes and behaviour, the so-called HRM outcomes, which in turn enhances organizational performance. Accordingly, Pfeffer (2000) observes that human resources have been essential in sustaining organizational performance.

Although, it has been generally agreed that HRM is positively associated with organizational performance, however, there is still need for additional research to be undertaken to provide more evidence to support the HRM-performance relationship from different cultural context such as Libya and other developing countries. Another issue here, is that authors have faulted the relationship between the HRM practices and organizational performance (Katou, 2008; Gerhart, 2005). They argued that their relationship lacks transparency about what exactly leads to what. Based on this, they suggested intervening or intermediary steps in the relationship between HRM practices and performance (Becker \& Gerhart, 1996). This indicates that the introduction of mediator and moderator in the relationship between HRM practices and organizational performance. Relying on this argument, this study opts for intervening step where HRM Outcomes in particular "employee retention" would mediate the relationship between HRM practices and organizational performance. In the previous studies of HRM practices and organizational performance, employee retention, one of HRM Outcomes components has not been adequately covered (Bowen \& Ostroff, 2004 and Collins $\&$ Smith, 2006). Therefore, for adequate understanding on the relationship between HRM practices and organizational performance, Wright, Gardner, Moyiham \& Allen, 2005; Purcell, Kinnie, Hutchinson, Rayton \& Swart (2003) have called on subsequent studies to interrogate the mediating role of HRM Outcomes such as employee retention in the relationship between HRM practices and organizational performance. Therefore, the major objective of this study is to investigate the mediating effect of HRM Outcomes (employee retention) on the relationship between HRM practices and organizational performance. 


\section{LITERATURE REVIEW}

\section{HRM Practices}

Experience has shown that some HRM policies and practices always do better than others, and thus all organizations or firms are implored to adopt the best practices. Although abundant studies may be claimed to exit in the HRM practices, however, a lot of these studies examining human resource practices issue only focused on certain variables. A review of literature conducted by Khan (2010) identified five key HRM practices, that is, training and development, recruitment and selection, compensation and reward, performance appraisal, and employee participation. Interestingly, these practices are part of the ten HRM practices that will be utilized in this study to evaluate the impact of these HRM policies on organizational performance.

\section{Organizational Planning}

Empirical research shows that the establishment of well defined organizational goals and objectives influence or shape employee retention and job productivity. For instance Kim et al. (2005) cited in Morncaz, Zhao \& Kay (2009) found that organizational direction and support impact on employee job satisfaction including the overall organizational commitment. Accordingly, empirical study by Susskind et al. (2000) noted that perceived organizational support strongly influences job satisfaction and employees' commitment to their organizations. Another study by the US Department of Labor (1993) on high performance work practices showed that including employees in decision-making, goals and the organizational direction via team participation would assist to produce job satisfaction and decrease turnover. Also many other previous studies found that "other work practices, such as total quality management and result in productivity gains have positive impact on motivation and commitment to the organization" (Huselid, 1995; MacDuffie, 1995; Osterman, 1994; Pfeffer, 1994). It is therefore not surprising that organizations which incorporate high-performance work practices such as employee participation or engagement, and total quality management are more likely to experience lower turnover rates for non-managerial employees because they help to induce job satisfaction (Huselid, 1995; Pfeffer, 1994; Cho et al. 2006).

\section{Staffing}

The staffing selectivity process plays essential roles in the workforce planning process. Although, the selectivity process is one of the difficult tasks to perform, however, it has a major influence on organizational performance. The organizational performance also will depend on the right number of workers, the proper required skills and motivated workers with positive behaviour to increase organizations performance (Größler and Zock, 2010). Wilk and Cappeli (2006) have noted that not all the staffing selectivity process are suitable to apply because some of the selection tools are costly and some are suitable only for certain organizations. Proper choices or selection tools in staffing selectivity process is very important in order to get correct information about candidates for correct positions within organizations. Hagan et al. (2006) noted that staff selection depends on the understanding the 
job, sufficient performance and outcomes, and motivated individuals. Although, for this to be effective, the whole process of selecting candidates should also be based on the compatibility between workgroup in term of values, goals, personality, behavior and as well as skills (Levesque, 2005).

\section{Training and development}

Training and development deals with the skills and competencies of the employees acquired through series of training and development programmes. In today's competitive environment driven by the knowledge economy, certain attributes and competencies of personnel are an integral component of organizations' competitiveness. There is no doubt that highly knowledgeable and skilled subordinates or employees will enhance productivity, improve quality of goods and services, bring positive changes in processes and help to deliver quality service to clients. In other words they enhance an organisation's competitiveness and performance. In essence, training and development yields tangible outcomes such as enhanced productivity, superior quality of products and services, and resource maximization or optimization. It also generates intangible results such as: high self esteem, enhanced morale, and satisfaction of subordinates which is as a result of additional skills, knowledge and abilities gained during the training and development programmes(SKAs). Due to the importance of training and development, Kundu (2000) has advised that firms should invest heavily in training their employees for effective implementation of customer-oriented strategies. Similarly, Blair and Sisakhti (2007) established that investments on training and development produce enormous benefits. Authors like Bitner \& Zeithmal (2004) have affirmed that expenditures on training and training yields strategic competitive advantage to firms and organizations. Jarventaus (2007) also affirmed that a dynamic business environment requires organizations that invest heavily on the training of their employees as this helps to develop organizational ability which enables them to positively respond to new challenges. Other studies have also found that comprehensive training and development programs are positively related to staff retention, productivity, and organizational effectiveness (Lee \& Bruvold, 2003; Arago'n-Sa'nchez et al. 2003). Jarventaus (2007) and Delaney \& Huselid (1996) have reaffirmed the presumed positive relationship between training and development, and organizational performance. Overall, training and development is significantly related to organizational performance.

\section{Performance appraisal}

The performance appraisal process is an activity that ensures mutual understanding between the subordinate and the supervisor through the process of evaluating directly the subordinate job specific performance priorities and expectations, communication, and assigned responsibilities. It is also a process of providing episodic and scheduled feedback that seeks to enhance teamwork and promote greater efficiencies and abilities.

Existing literature has shown that performance appraisal is positively related to organizational performance. Lee and Lee (2007) established that successful performance appraisal systems enhance quality and productivity. Accordingly, Sang (2005) found that a comprehensive, transparent and client-based performance appraisal system enhances firm 
performance. Similarly, Rahman (2006) established that a comprehensive performance appraisal system increases subordinates' commitment. Brown and Hewood (2005) contended that the process of performance appraisal system has a positive association with enhanced productivity of firms. Cook \& Crossman (2004) affirmed the relationship between employees and supervisors which is facilitated by performance. From the above, there is a clear indication that performance appraisal is an important instrument to base career development, recognition, and promotion of employees (Larsson et al. 2007). Supporting this, Hanley (2005) argued that performance appraisal is a more productive process that influences organizational performance. Conclusively, Ahmed \& Shroedrs (2003) and Chang \& Chen (2002) in their individual research established a strong positive link between organizational performance and the process of performance appraisal.

\section{Compensation and Reward}

Generally, it is argued that a comprehensive compensation blend complemented by an effective disbursement system plays a valuable task in attracting the best applicants. Previous studies in HMR have documented the importance compensation and reward. For instance, most of these studies have found that an effective compensation and reward process enhances productivity, sales and overall organizational performance (Delaney \& Huselid, 1996; Dreher \& Dougherty, 2005). Accordingly, Chiu et al. (2002) stated that rewards and compensation considerably affect organizational outcomes. Equally Jyothi and Venkatesh (2006) established that competency-based rewards and pay enhances the quality of goods and services, improves subordinates' behaviour, and decreases accidents rates in organizations, thereby improving organizational performance. Milkovich \& Newman (1999) noted that the activity of compensation encompasses all forms of monetary returns and related services provided to subordinates or employees. Certainly, employee competencies improve organizational performance by inference enhances effectiveness. No wonder Berndardin and Russel (1993) noted that reward planning and compensation are key dimensions of potent HRM practices. In support of this, Mathis and Jackson (2004) posited that a balanced, transparent and competitive reward and compensation system influence the retention of talents. Therefore, there is clear evidence that compensation and reward effectively affect organizational performance.

\section{HRM Outcome (Employee Retention)}

Retention according to (Chaminade, 2007) is a voluntary move by an organisation to create an environment which engages employees for long term". Therefore, employee retention is a voluntary effort by any organization to provide an environment which tends to keep or retain employees for a long period. Similarly, Kyndt, Dochy, Michielsen and Moeyaert (2009) defined employee retention as the practice and method or whatever organization does to have and retain skilled employees.

In the recent times, researchers and scholars have found that though human resources management does influence performance, however, "there is little understanding of the mechanisms through which HRM practices influence effectiveness" (Delery, 1998, p. 289). 
Boselie et al. (2005) has labeled some aspects of HRM-performance as a "black box" due to the fact that they have been neglected.

As a result of this, authors like (Katou, 2008; Paauwe and Richardson, 1997) have conducted research with attendant concepts and models so as to adequately comprehend and untangle the puzzle that underpins the HRM-performance relationship including intermediary factor like employee retention. Notably, the intermediary stage of this relationship, usually comprise the HRM outcomes of motivation, satisfaction, social climate, retention, involvement, loyalty and trust (Paauwe and Richardson, 1997). Within the context of this discussion, Boselie et al. (2005) has identified the little attention which extended to exploring the linking mechanisms or mediating effects of crucial factors in the HRM- performance relationship. Although, there are many components of HRM Outcome as indicated earlier, however, this is study focuses on one aspect of HRM Outcomes that is, employee retention.

Since the mid-1990s, empirical studies have concentrated not only on finding why employees or workers desert organizations but also looking at those factors and aspects that could significantly impact on employees to remain in the organization and the benefits associated with retaining workers (Moncarz, Zhao, \& Kay, 2009). In the recent time, Bairi, Manohar \& Kundu (2011) have acknowledged that employee retention has emerged as the focus point of many researches in the field of HRM, particularly as part of talent management programs in which many of the human resources practitioners have integrated into the program (Law, 2003; Gallagher et al. 2006). On the contrary, Huang, Lin, \& Chuang (2006) in their studies have observed that despite the emerging importance of employee retention, only few studies have examined the concept. Furthermore, Huang et al. (2006) argued that most existing studies tend to focus more on turnover than on retention, itself.

To enhance organizational performance and improve the relationship between HRM practices and organizational performance, organization must develop retention strategies such as rewards, autonomy and image (Development and Learning in Organizations, 2011). In this case, they should be an integrated set of human resource capabilities or assets to address employee retention challenges (Bairi, Manohar \& Kundu (2011). Accordingly, factors such as: incentive, compensation, competitive and fair wages etc would encourage or motivate employees to stay in organization for longer time (Sigler, 1999). Finally, it is being argued here that employee retention would mediate the relationship between HRM practices and organizational performance. We therefore, proposed that the presence of employee retention will enhance the organizational performance and further improve the relationship between HRM practices and organizational performance.

\section{Organizational Performance}

Commonly, researchers and scholars have utilized both non-financial and financial metrics to measure firm or organizational performance (Dyer \& Reeves, 1995; Khan, 2010). Thus, both non-financial and financial measures are most used by the researchers. Some of the financial measures are sales, profit, and market share while non-financial measures also may include 
the followings: efficiency, quality, productivity, and the behavioral and attitudinal measures such as satisfaction, intention to quit, and commitment. Hoskisson et al. (2000) has argued on the difficulties pertaining to the measurement of financial dimensions in developing economies. They noted that factors such as: lack of market-focused financial reporting, lack of fairness in financial reporting, insufficient regulatory mechanism and enforcement about financial reporting, and provision of fabricated financial information are key issues confronting developing countries in which Libya upon which the present study is being conducted is not left out. In the case of non-objective measure, it usually compels decision makers to take into consideration organizational goals when assessing its performance.

In a HRM studies, both financial and non-financial measures of performance have been well utilized. However, the arguments about what elements or components which are to be included as the indicators is still not clear. For instance, Boselie et al. (2005) pointed out the importance of both internal and external factors. Furthermore, factors such as: productivity, absenteeism, employees turnover intentions, job satisfaction, subordinates' stress level, quality of product and service, trust in management, commitment etc have been included in the performance measure (Boselie et al. 2005; Huselid, 1995; Chang \& Chen, 2002; Guest, 2003; Batt, 2002; Lowe et al. 1997; MacDuffie, 1995; Whitener, 2001; Tsui et al. 1997; Ramsay et al. 2000; Youndt et al. 1996; Delaney \& Huselid, 1996; Powell, 1992 and Geringer \& Hebert, 1991).

In view of the above discussion, this study conceptualizes organizational performance from multiple dimensions encompassing satisfaction, employee relations, turnover intention and organizational climate. Tseng and Lee (2009) noted that integrating multiple dimensions will no doubt improve the environmental fit of the study and adaptive organizational strategies.

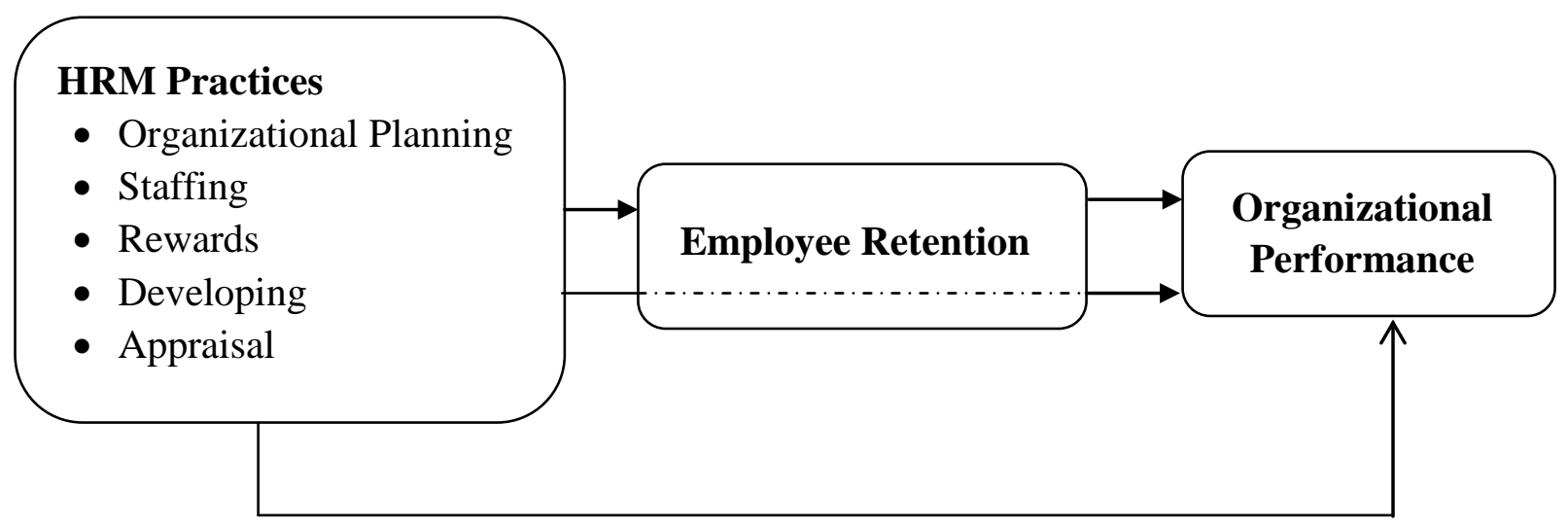

Figure 1: Proposed Research Framework

The study is based on the above framework that is developed through the extensive literature review and information from several dimensions. For the independent variable (HRM practices), five dimensions are being identified and they are based on the previous work of Rizov and Croucher (2008), Katou \& Budhwar (2006); Paul and Ananatharaman (2003), Harel and Tzafrir (1999). For employee retention, it is adopted from the works of Katou (2008) and Paauwe and Richardson (1997), it stands as the mediating variable and it mediates between the independent and the dependent (organizational performance) variables, that is, in 
the relationship between HRM practices and organizational performance.

The study used the "Resources Based View theory" by Penrose to underpin the framework. According to Priem and Butler (2001), organization resources include: "all assets, capabilities, organizational processes and attributes, HRM practices, and most importantly, the employees in the organization. These employees must be hired and retained at all cost to enable the organization achieve a better organizational performance. The RBV theory gives the organization a competitive advantage through strategy such as "employee retention" strategy. Thus, organization must conceive of and implement strategies (e.g employee retention) that would improve its efficiency and effectiveness in particular organizational performance.

Based on the literature review and the proposed research framework above the following propositions are hereby formulated:

Proposition 1: HRM practices have a positive influence on organizational performance.

Proposition 2: HRM practices have a positive influence on employee retention.

Proposition 3: Employee retention has a positive influence on organizational performance.

Proposition 4: Employee retention mediates the relationship between HRM practices and organizational performance.

\section{Methodology}

\section{Population and Sampling}

The population of this study will include all government organizations or agencies having one form of HR practices or the other in Libya, that is, any government organization with HR practices. The study intends to get the list of government organization with HRM practices from the government company directory. In total, the number of government agencies in Libya is 484 . The researchers will use a systematic sampling technique to select 242 organizations by picking every $\mathrm{n}^{\text {th }}$ element from the population of the study. Hence, the study intends to contact 484 HRM managers of the selected companies. In other words, the unit of analysis for this study is organization with particular focus on the HR managers.

\section{Measurement}

To measure the variables in this study, a questionnaire survey will be utilized. The questionnaire will consist of two major parts: the respondents' profiles and their organizations while the part two which deals with variables under investigation will contain questions on HRM practices (Fong, Ooi, tan, Lee, and Chong, 2011; Kyndt et al., 2009; NYS Report, 2002; Chang and Chen, 2002), HRM Outcome (employee retention) and lastly, organizational performance. All the variables in this study will be measured using a five-point likert-scale of $1=$ strongly disagree to $5=$ strongly agree. It will measure the extent to which the respondents agree or disagree with each of the statement. The questionnaire will be adopted from the previous works of Antoncic (2011); Rogg, Schmidt, Shull and Schmitt (2001); Kang, Stewart and Kim (2011) and Guerrero and Herrbach (2009). 


\section{Analysis Techniques of Data}

Four major data techniques analyses will be applied to analysis the data to be collected from the field survey. First, the descriptive data analysis will be utilized to summarise the respondents' profile and their organizational. Second, the factor analysis will be applied to reduce the data to the acceptable limit. In this case, a component factor analysis with a varimax rotation will be utilized. Items having low loading factors less than 0.3 maybe dropped while items with factor loading above 0.3 maybe accepted. To confirm the hypotheses (propositions) in this study, a correlation analysis technique will be applied, this will assist in checking inter-relationship between variables and their direction of their relationship and after this, the regression analysis will be used to test the hypotheses. This will help to establish the nature of their relationship.

\section{Conclusion}

The paper examines the mediating effect of HRM outcomes on the relationship between the HRM practices and organizational performance. In particular, it investigates the mediating role of employee retention on the above relationship. Therefore, four major propositions (Proposition 1: HRM practices have a positive influence on organizational performance, Proposition 2: HRM practices have a positive influence on employee retention, Proposition 3: Employee retention has a positive influence on organizational performance and Proposition 4: Employee retention mediates the relationship between HRM practices and organizational performance) were advanced. As noted earlier, the significant positive relationship between HRM practices and organizational performance has been well documented. HRM practices have been noted to significantly affect organizational performance to a greater extent. Hence, it is a significant predictor of organizational performance. However, this relationship needs to be further improved. As a result of this, the study interrogated the mediating perspective of the relationship indicated above. In particular, the study used employee retention to mediate the relationship between HRM practices and organizational performance. Employee retention has emerged as one of the major focus in the recent years in HRM studies, particularly as part of talent management programs. The human resources practitioners have tried to integrate it into a talent program. To enhance organizational performance, organization must develop employee retention strategies such as rewards, autonomy and image. However, factors such as: incentive, compensation, competitive and fair wages etc should be considered in encouraging or motivating employees to stay in organization for longer time. It is only when this is done that employee retention would make a meaningful contribution in the relationship between HRM practices and organizational performance.

Conclusively, the paper contributes to body of knowledge by providing a conceptual framework to examine the mediating role of HRM Outcome in particular, employee retention on organizational performance specifically in Libya and as such would be of benefit to both HR managers and government in particular HR policy makers. 


\section{References:}

Ahmad, O., \& Schroeder, R. G. (2003). The impact of human resource management practices on operational performance: Recognizing country and industry differences. Journal of Operations Management, 21, 19-43.

Ahmad, S., \& Schroedar, R. G. (2002). The importance of recruitment and selection process for sustainability of total quality management. International of Quality and Reliability Management, 19(5), 540-550.

Antoncic, J. A., \& Antoncic, B. (2011). Employee satisfaction, intrapreneurship and firm growth: a

Model. Industrial management \& Data Systems, 111(4), 589-607

Arago'n-Sa'nchez, A., Barba-Arago'n, I., \& Sanz-Valle, R. (2003). Effects of Training on Business Results. International Journal of Human Resource Management, 14, 956-80.

Bairi, J., Manohar, B. M., \& Kundu, G. K. (2011). Knowledge retention in the IT service industry. Journal of Systems and Information Technology, 13(1), 43-65.

Batt, R. (2002). Managing customer services: Human resource practices, quit rates, and sales growth. Academy of Management Journal, 45, 587-597.

Becker, B. E., \& Gerhart, B. (1996). The impact of human resource management on organizational performance: Progress and prospects. Academy of Management Journal, 39 (4), 779-801.

Bernardin, H.J., \& Russell, J. E. A. (1993). Human resource management: An experiential approach. Singapore: McGraw-Hill Inc.

Bitner, M. J., \& Zeithaml, V. A. (2004). Service marketing. New York: McGraw Hill.

Blair, D., \& Sisakhti, R. (2007). Sales training: what makes it work"? T+D Magazine, August, available at: www.astd.org/astd/Publications/ TD Magazine/ 2007_pdf/August/0708_ExecSum.htm.

Boselie, P., Dietz, G., \& Boon, C. (2005). Commonalities and contradictions in HRM and performance research. Human Resource Management, Journal, 15, 67-94.

Boselie, P., Dietz, G., \& Boon, C., (2005). Commonalities and contradictions in HRM and performance research. Human Resource Management Journal,15(3).

Boselie, P., Paauwe, J., \& Jansen, P. (2001). Human resource management and performance: lessons from the Netherlands. International Journal of Human Resource Management, 12, 1107-1125.

Bowen, D. E., \& Ostroff, C. (2004). Understanding HRM-firm performance linkages: The role of the "Strength" of the HRM system" Academy of Management Review, 29(2), 203-221.

Brown, M., \& Heywood, J. S. (2005). Performance appraisal systems: determinants and change. British Journal of Industrial Relations, 43(4), 659-679.

Collins, C. J., \& Clark, K. D. (2003). Strategic human resource practices, top management team social networks, and firm performance: the role of human resource practices in creating organizational competitive advantage. Academy of Management Journal, 46(6), 740-751.

Collins, C. J., \& Smith, K. G. (2006). Knowledge exchange and combination: The role of human resource practices in the performance of high-technology firms. Academy of Management Journal, 49(3), $544-560$.

Cook, J., \& Crossman, A. (2004). Satisfaction with performance appraisal systems: a study of role perceptions. Journal of Managerial Psychology, 19(5), 526-541.

Cooke, W. (1994). Employee participation programmes, group based incentives and company performance: 
a union-non union comparison. Industrial and Labour Relations Review, 47(4), 594-609.

Chang, P. L., \& Chen, W. L. (2002). The effect of human resource management practices on firm performance: Empirical evidence from high-tech firms in Taiwan. International Journal of Management, 19(4), 622-631.

Cho, S., Woods, R. H., Jang, S. C., \& Erdem, M. (2006). Measuring the impact of human resource management practices on hospitality firms' performances. International Journal of Hospitality Management, 25(2), 262-277.

Delaney, T. J. \& Huselid, A. M. (1996). The impact of human resource management practices on perceptions of organizational performance. Academy of management journal, 39(4), 949-969

Delery, J., \& Doty, D. H. (1996). Modes of theorizing in strategic human resource management: test of universalistic, contingency and configurational performance predictions. Academy of Management Journal, $39,802-835$.

Dougherty, J. (2004). Why learning isn't about learning. Journal of European Industrial Training, 4 (11), 46-7.

Doyle, M. (2002). Selecting managers for transformational change. Human Resource Management Journal, 12(1), 3-16.

Dreher, G.F. \& Dougherty, T.W. (2005). Human Resource Strategy: A Behavioral Perspective for the General Manager. New Delhi: Tata McGraw-Hill Publishing Company Limited.

DLO (2011) "Putting people first: Employee retention and organizational performance", Development and Learning in Organizations, 25( 1), $25-27$

Dyer, L., \& Reeves, T. (1995). Human resource strategies and firm performance: What do we know and where do we need to go? Paper presented at the 10th World Congress of the International Industrial Relations Association. Washington, DC.

Fong, C. Y., Ooi, K. B., Tan, B. I., Lee, V. H., \& Chong, A. Y. L. (2011). HRM practices and knowledge Sharing: an empirical study. international Journal of Manpower, 32(5/6), 704-723

Gallagher, D. G., \& McLean Parks, J. (2001). I pledge thee my troth . . contingently: Commitment and the contingent work relationship. Human Resource Management_Review, 11, 181-208.

Gerhart, B. (2005). Human resources and business performance: findings, unanswered questions, and an alternative approach. Management Revue, 16, 174-185

Gerhart, B., \& Mikovich, G.T. (1992). Employee compensation: Research and practice. In M. D. Dunnette, and L.M. Hough, (Eds.), Handbook of Industrial Psychology (pp. 481-569). Palo Alto, CA: Consulting Psychologists Press.

Geringer, M. J., \& Hebert, L. (1991). Measuring performance of international joint ventures. Journal of International Business Studies, 28, 249-63.

Guerrero, S., \& Herrbach, O. (2009). Retracted: The impact of development and information sharing practices on employee retention-related attitudes: exploring the meditaing role of organizational trust. Human resources management Journal

Guest, D., \& Conway, N. (2004). Employee well-being and the psychological contract: a report for the CIPD. Chartered Institute of Personnel and Development, London .

Größler, A., Zock, A, (2010). Supporting long-term workforce planning with a dynamic aging chain model; 
a case study from the service industry. Human Resource Management 49(5), 829-848.

Hagan, C .M., Konopaske ,R., Bernardin, H. J., Tyler, C.L. (2006). Predicting assessment center performance with 360-degree, top down, and customer based competency assessments. Human Resource Management 45(3), 357-390.

Hanley, G. (2005). Right on the money: what do Australian Unions think of performance related pay? Employee Relations, 27(2), 141-159.

Harel, H.G., \& Tzafrir, S. S. (1999). The effect of human resource management practices on the perceptions of organizational and market performance of the firm. Human Resource Management, 38 (3), 185-99.

Hoskisson, R.E., Eden, L., Lau, C.M., \& Wright, M. (2000). Strategy in emerging economies. Academy of Management Journal, 43(3), 249-267.

Huang, C., Lin, H. C., \& Chuang, C. H. (2006). Constructing factors related to worker retention. International Journal of Manpower, 27(5), 491-508.

Huselid, M. A. (1995). The impact of human resource management practices on turnover, productivity, and corporate financial performance. Academy of Management Journal, 38, 653-72.

Jarventaus, J. (2007). Training in a risky industry. $T+D$ Magazine, available at: www.astd.org/astd/Publications/TD Magazine/2007_pdf/March/0703 Ex ecSum.htm.

Jyothi, P., \& Venkatesh, D.N. (2006). Human Resource Management. New Delhi:Oxford University Press.

Kang, D., Stewart, J., \& Kim, H. (2011). The effects of perceived external prestige, ethical organizational climate, and leader-member exchange (LMX) quality on employees' commitement and their subsequent attitudes. Personal review, 40(6), 761-784

Katou, A. A. (2008). Measuring the impact of HRM on organizational performance. School of Industrial and Aeronautic Engineering of Terrassa (ETSEIAT). Universitat Politècnica de Catalunya (UPC).

Katou, A. A, \& Budhwar, P. S. (2006). The effect of human resource management policies on organizational performance in Greek manufacturing firms. Thunderbird International Business Review 49(1), 1-35.

Khan, A. M. (2010). Effects of human resource management practices on organizational performance: An empirical study of oil and gas industry in Pakistan. European Journal of Economics, Finance and Administrative Sciences, 24, 157-174.

Kim, W., Leong, J. and Lee, Y. (2005), "Effect of service orientation on job satisfaction, organizational commitment, and intention of leaving in a casual restaurant". International Journal of Hospital management, 24(2), 171-193

Kundu, S.C. (2000). Creating Constituent Capitalized Workforce for Delivering Service Quality: A Challenge for the $21^{\text {st }}$ century. In M. Raghavachari and K.V Ramani (Eds.), Delivering Service Quality: Managerial Challenges for the $21^{\text {st }}$ Century (pp.232-239). Macmillan India Limited, Delhi.

Kyndt. E., Dochy, F., Michielsen, M. \& Moeyaert, B (2009). Employee Retention: Organisational and Personal Perspectives. Vocations and Learning, 2, 195-215

Law, A. (2003), "The aging workforce raises new talent management issues for employers",Journal of Organizational Excellence, 23, 55-66. 
Lee, F., \& Lee, F. (2007). The relationships between HRM practices, leadership style, competitive strategy and business performance in Taiwanese steel industry. Proceedings of the 13th Asia Pacific Management Conference, Melbourne, Australia, 953-971.

Lowe, J., \& Delbridge, R. (1997). Managing Human Resource for Business Success: a review of the issues. International Journal of Human Resource Management, 8 (6), 857-873.

Levesque, L. L, (2005). Opportunistic hiring and employee fit. Human Resource Management 44(3), 301-317.

MacDuffie, J. P. (1995). Human resource bundles and manufacturing performance: organizational logic and flexible production systems in the world auto industry. Industrial and Labor Relations Review, 48, 197-221.

Malvern, W. C., Michael, O. S. and Crispen, C (2010). An examination of employee retention strategy in a private organisation in Zimbabwe. African Journal of Business Management, 4(10), 2103-2109

Mathis, R. L., \& Jackson, J. H. (2004). Human resource management. Singapore Thomson Asia Pte. Ltd. Milkovich, G. T., \& Newman, J. M. (1999). Compensation. New York: Irwin/McGraw-Hill.

Moncarz, E., Zhao, J., \& Kay, C. (2009). An exploratory study of US lodging properties' organizational practices on employee turnover and retention. International Journal of Contemporary Hospitality Management, 21(4), 437-458.

NYS Department of Civil Service Report (2002). Report of the Employee Retention Workgroup. NYS Governor's Office of Employee Relations

Osterman, P. (1994). How common is workplace transformation and who adopts it? Industrial and Labor Relations Review, (47), 173-88.

Paauwe, J. and Richardson, R. (1997), Introduction special issue on HRM and Performance, International Journal of Human Resource Management, 8( 3),257-262.

Paul, A. K., \& Anantharaman, R. N. (2003). Impact of people management practices on organizational performance. International Journal of Human Resource Management, 14, 1246-1266.

Pfeffer, J. (1994). Competitive advantage through people: Unleashing the power of the work force. Harvard Business School Press, Boston, MA.

Pfeffer, J. (2000). Seven practices of successful organizations. In W. L. French, C.H. Bell., \& J. Pfeffer (Eds.). Seven practices of successful organizations (pp. 96-124). California Management Review.

Powell, T. C. (1992). Organizational alignment as a competitive advantage. Strategic Management Journal, 13, 119-34.

Priem, R. L. and Butler, J. E. (2001). The Resource-Based "View" a Useful Perspective for Strategic Management Research? The Academy of Management Review, 26(1), 22-40

Purcell, J., Kinnie, N., Hutchinson, S., Rayton, B., \& Swart, J. (2003). Understanding the people and performance link: Unlocking the black box. London: Chartered Institute of Personnel and Development.

Rahman, S. A. (2006). Attitudes of Malaysian teaches towards a performance appraisal system. Journal of Applied Social Psychology, 36(12), 3031-3042.

Ramsay, H., Scholarios, D., Harley, B. (2000). Employees and high-performance work systems: Testing inside the black box. British Journal of Industrial Relations, 38 (4), 501-31

Rizov, M., \& Croucher, R. (2008). Human resource management and performance in European firms. Cambridge Journal of Economics, 33, 253-272. 
Rogg, K. L., Schmidt, D. B., Shull, C., \& Schmitt, N. (2001). Human resource practices, organizational climate, and customer satisfaction. Journal of Management, 27(4), 431-449

Sang, C. (2005). Relationship between HRM practices and the perception of organizational performance, roles of management style, social capital,and culture: comparison between manufacturing firms in Cambodia and Taiwan. National Cheng Kung University, Tainan, Taiwan.

Sigler, K. J. (1999). Challenges of employee retention. Management Research News, 22(10), 1-5.

Trulson, G.S. (2004). Employee retention of public safety dispatchers. National Fire Academy, Emmitsbury, Maryland.

Tseng, Y. F., \& Lee, T. Z. (2009). Comparing appropriate decision support of human resource practices on organizational performance with DEA/AHP model. Expert Systems with Applications, 36(3), 6548-655 Tsui, A., Pearce, J., Porter, L. \& Tripoli, A. (1997). Alternative approaches to the employee-organization relationship: Does investment in employees pay off? Academy of Management Journal, 40, 1089-1121.

US Department of Labor (1993), High Performance Work Practices and Firm Performance, Government Printing Office, Washington, DC.

Whitener, E. M. (2001). Do "high commitment" human resource practices affect employee commitment? A cross-level analysis using, hierarchical linear modeling. Journal of management, 27, 515-535

Wilk, S. L., Cappelli, P. (2006). Understanding the determinants of employer use of selection methods. Personal Psychology Inc, 56, 103-124.

Wright, P. M., Gardner, T. M., Moynihan, L. M., \& Allen, M. R. (2005). The relationship between HR practices and firm performance: Examining causal order. Personnel Psychology, 58, 409-446.

Youndt, M. A., Snell, S. A., Dean, J. W., \& Lepak, D. P. (1996). Human resources management, manufacturing strategy, and firm performance. Academy of Management Journal, 39, 836-65. 